\title{
PENGARUH KONSELING KELOMPOK DENGAN PENDEKATAN ADLERIAN TERHADAP PENINGKATAN PEMAHAMAN DIRI SISWA KELAS 5 SDN 01 UJUNG MENTENG
}

\author{
Fauzie Firmansyah Setiawan ${ }^{1}$ \\ Dra. Wirda Hanim, M.Psi. ${ }^{2}$ \\ Happy Karlina Marjo, M.Pd., Kons ${ }^{3}$
}

\begin{abstract}
Abstrak
Tujuan penelitian ini adalah untuk mendapatkan data empiris tentang pengaruh konseling kelompok dengan pendekatan Adlerian terhadap peningkatan pemahaman diri siswa kelas 5 SDN 01 Ujung Menteng.Metode yang digunakan adalah kuasi eksperimen dengan pretest-posttest nonequivalent group design.Sampel dalam penelitian ini diambil dengan menggunakan teknik purposive sampling. Uji coba intrumen dilakukan terhadap 54 responden.Pengujian perhitungan validitas instrumen diolah menggunakan Microsoft Excel dengan rumus Product Moment. Hasil perhitungan validitas menyatakan 24 butir item valid dan 18 butir item tidak valid, sedangkan reliabilitas intrumen dihitung menggunakan rumus Alpha menunjukkan 0.754 yang berarti intrumen termasuk dalam kategori reliabilitas yang tinggi. Teknik analisis data untuk hipotesis menggunakan Mann Whitney U-Test. Hasil uji hipotesis dilakukan dengan bantuan program SPSS 17.0 for windows yang menunjukan bahwa nilai Asymp. sig sebesar 0,001, yang berarti lebih kecil dari nilai signifikansi a 0,05, sehingga dapat disimpulkan bahwa HO ditolak dan H1 diterima, karena skor rata-rata peningkatan pemahaman diri siswa yang mendapatkan perlakuan berupa konseling kelompok dengan pendekatan Adlerian lebih tinggi yaitu 62,3 berbanding dengan 45,5 skor rata-rata pemahaman diri siswa yang tidak mendapatkan perlakuan berupa konseling kelompok dengan pendekatan Adlerian.Kesimpulan berdasarkan hasil penelitian ini, konseling kelompok dengan pendekatan Adlerian dapat meningkatkan pemahaman diri siswa kelas 5 SDN 01 Ujung Menteng.
\end{abstract}

Kata Kunci : Pemahaman Diri, Konseling Kelompok dengan Pendekatan Adlerian

\section{Pendahuluan}

Penanaman karakter melalui pendidikan, khususnya di tingkat SD dinilai tepat karena sesuai dengan tugas perkembangan yang harus dicapai dan sesuai dengan tujuan pendidikan itu sendiri. Thomas Lickona mengatakan bahwa pendidikan karakter meru- pakan sebuah pendidikan yang di dalamnya melibatkan komponen pemahaman moral (Moral Knowing), perasaan moral (Moral Feeling), dan perilaku moral (Moral Action) yang nantinya ketiga aspek ini merupakan proses yang harus dilewati setiap individu untuk membangun moral (Thomas Lickona,

\footnotetext{
Mahasiswa Jurusan Bimbingan dan Konseling FIP UNJ, Fauziefirmansyah.s@gmail.com

2 Dosen Bimbingan dan Konseling FIP UNJ, Wirdahanim10@gmail.com

3 Dosen Bimbingan dan Konseling FIP UNJ, Happykarlina.unj2005@gmail.com
} 
1991:52).

Salah satu aspek di dalam karakter baik yang dikembangkan oleh Thomas Lickona adalah pemahaman diri. Menurut Susan Harter yang dimaksud dengan pemahaman diri adalah proses memahami secara mendalam berbagai karakteristik diri yang meliputi potensi dan kekurangan yang ada (Marcia Cavell, 1990:197). Dapat disimpulkan bahwa pemahaman diri adalah kemampuan memahami secara mendalam berbagai karakteristik diri yang meliputi potensi-potensinya, baik potensi fisik maupun potensi psikis.

Pemahaman diri penting dimiliki oleh setiap siswa SD, karena setelah siswa mampu memahami dirinya, diharapkan siswa dapat mengoptimalkan potensi dan kelebihan yang dimiliki untuk mencapai kesuksesan di masa mendatang, baik kesuksesan dalam hal belajar, berkarier, bergaul, berkeluarga, maupun bermasyarakat. Tidak hanya itu siswa yang mampu memahami dirinya juga diharapkan dapat menerima kekurangan yang dimiliki untuk diminimalisir atau dihilangkan, sehingga tidak menimbulkan suatu masalah dalam kehidupan individu di masa mendatang. Memiliki pemahaman diri yang baik tidaklah mudah karena setiap siswa memiliki kadar yang berbeda untuk bisa mengenali dirinya sendiri, bahkan tidak jarang banyak siswa yang belum bisa mengenali dirinya sendiri.

Salah satu layanan yang mungkin dapat diberikan oleh konselor di jenjang SD dalam mengatasi permasalahan di atas adalah konseling kelompok. Konseling kelompok dinilai cocok diterapkan kepada siswa SD karena di dalam sebuah kelompok siswa dapat saling berinteraksi dan saling mempengaruhi satu sama lain, sehingga kegiatan yang dilakukan secara berkelompok dapat mengembangkan keterampilan sosial siswa. Ada banyak pendekatan yang dapat digunakan dalam konseling kelompok, salah satunya adalah pendekatan Adlerian. Melalui pendekatan konseling kelompok Adlerian, siswa SD yang memiliki permasalahan dengan pemahaman dirinya akan diarahkan untuk membangun kembali tujuan dan gaya hidup yang sudah terbentuk, sehingga dapat membantu siswa dalam menyelesaikan masalah yang dihadapi. Konseling kelompok dengan pendekatan Adlerian juga akan membantu siswa
SD dalam menumbuhkan minat sosial, agar siswa dapat mengembangkan potensi yang dimiliki secara kreatif.

Berdasarkan pembahasan di atas, konseling kelompok dengan pendekatan Adlerian diharapkan dapat meningkatkan pemahaman diri siswa kelas 5 SDN 01 Ujung Menteng.

\section{Kajian Teoretik \\ Pemahaman Diri}

Susan Harter mendefinisikan pemahaman diri sebagai proses memahami secara mendalam berbagai karakteristik diri yang meliputi potensi dan kekurangan yang ada (Marcia Cavell, 1990: 197). Sementara Thomas Lickona berpendapat pemahaman diri merupakan keadaan di mana seseorang telah mengetahui kekuatan, kelemahan yang dimiliki, dapat mengembangkan kekuatan dan menutupi kelemahan tersebut, serta mampu mengevaluasi atas perilaku yang ditampilkan, guna mempe-ngaruhi kualitas hidup (Thomas Lickona, 1991:54).Definisi tersebut menekankan dalam istilah memahami bukan sekadar mengandung makna mengetahui, akan tetapi mampu menjelaskan, menilai, serta menganalisis berbagai karakteristik yang ada di dalam diri, sehingga orang yang telah memahami dirinya akan paham tentang keadaan dirinya dan juga posisi dirinya dalam lingkungan.

Lebih luas Ridwan mengemukakan bahwa pemahaman diri tidak hanya sebatas tentang pemahaman terhadap diri sendiri, namun lebih dari itu. Pemahaman diri juga merupakan pemahaman sebagai diri pribadi, sosial, dan spiritual (Ahmad Sobur, 2003:27).Pendapat di atas menunjukan bahwa pemahaman diri dapat berkembang melalui pengalaman-pengalaman yang diperoleh dari interaksi dengan lingkungan.

Merujuk dari definisi yang telah dijelaskan beberapa ahli di atas, peneliti menyimpulkan bahwa pemahaman diri merupakan kemampuan seseorang melihat secara mendalam akan karakteristik dirinya yang mencakup kekuatan dan kelemahan yang ada pada diri serta mampu menganalisis, bagaimana cara mengembangkan kekuatan dan dapat menutupi kelemahan yang ada. 


\section{Konseling Kelompok dengan Pendekatan Adle-} rian

Psikologi yang digunakan oleh Adler adalah "Psikologi Individual" yang merupakan terjemahan dari Individual Psychologie, dalam bahasa Jerman kalimat tersebut diartikan menjadi psikologi sosial yang memiliki makna bahwa individu dilihat dan dipahami dalam konteks sosialnya (Yustinus Semiun, 2013:209).

Adler yakin bahwa minat sosial manusia merupakan dorongan alami yang dibawa sejak lahir dan bukan muncul secara spontan, tetapi harus ditumbuhkan lewat bimbingan dan latihan (Ahmad Supratik, 1993:249). Dorongan alami yang dimiliki oleh manusia akan memotivasi individu untuk dapat terlibat dalam berbagai tugas kehidupan yang sangat penting dalam perkembangan psikologis dan kesehatan mental seseorang.

Menurut Adler permasalahan yang dihadapi oleh manusia akan selalu bersifat sosial, sehingga fungsi hidup sehat bukan hanya mencintai dan berkarya tetapi juga merasakan kebersamaan dengan orang lain dan memperdulikan kesejahteraan mereka. Oleh karena itu, dalam teorinya Adler mengembangkan lima pokok-pokok yang berkaitan dengan manusia, yaitu: perjuangan menuju kesuksesan atau superioritas, persepsi subjektif, minat sosial, gaya hidup dan urutan kelahiran (Alwisol, 2011:63).

Mengacu pemaparan di atas mengenai pokok-pokok dasar pandangan Adler terhadap manusia, maka pemahaman diri sejalan dengan konsep minat sosial teori Adler. Menurut Adler minat sosial yang membuat orang mampu berjuang mengejar superioritas dengan cara yang sehat dan tidak tersesat. Artinya orang yang telah memiliki minat sosial yang baik akan berjuang bukan hanya untuk superioritas pribadi, melainkan untuk kebaikan dan kesempurnaan semua orang, sehingga orang tersebut mampu untuk bekerja sama dengan orang lain yang tidak hanya mementingkan keuntungan pribadi semata.

Menurut Dreikurs terdapat empat tahap dalam konseling kelompok dengan pendekatan Adlerian, yaitu: Membangun hubungan, Investigasi psikologis, Pengungkapan psikologis dan Reorientasi (Manford Sonstegard, 2004:23).

\section{Metode Penelitian}

Penelitian dilakukan di SDN 01 Ujung Menteng yang beralamat di Jl. Irigasi Ujung Menteng, RT 01 RW 08, Kecamatan Cakung, Jakarta Timur.Penelitian dilakukan mulai bulan Maret hingga Desember 2014.

Metode yang digunakan dalam penelitian ini adalah metode quasi experimental design dengan nonequivalent group design. Penelitian nonequivalent group design akan menggunakan satu kelompok eksperimen yang diberi perlakuan dan satu kelompok kontrol untuk perbandingan yang tidak diberi perlakuan (Sugiyono, 2008:116).

Teknik sampling yang digunakan dalam penelitian ini adalah purposive sampling. Purposive sampling merupakan teknik sampling yang berdasarkan pada ciri-ciri yang dimiliki oleh subjek karena ciriciri tersebut sesuai dengan tujuan penelitian yang akan dilakukan (Sugiyono, 2008:68). Sampel pada penelitian ini berdasarkan pada hasil pretest dengan instrument pemahaman diri yang skornya masuk dalam kategori rendah.Ada pun dari hasil pretest, diperoleh sebanyak 8 siswa dari kelas $5 \mathrm{~A}$ dan sebanyak 8 siswa dari kelas 5B yang memiliki skor pemahaman diri dengan kategori rendah.

Pengujian validitas butir instrumen menggunakan rumus Pearson Product Moment, sedangkan dalam menguji reliabilitas instrumen pada penelitian menggunakan rumus Alpha Cronbach. Dari hasil uji reliabilitas yang telah dilakukan pada butir pernyataan yang valid diperoleh angka reliabilitas sebesar 0.754 yang artinya masuk dalam kategori tinggi, maka dengan demikian instrumen pemahaman diri reliabel dan layak digunakan sebagai alat ukur dalam penelitian.

Teknik analisis data yang digunakan dalam penelitian ini adalah Mann Whitney U-Test dengan menggunakan bantuan aplikasi SPSS for Windows versi17.0.Mann Whitney U-Test digunakan untuk menguji hipotesis komparatif dua sampel independen bila datanya berbentuk ordinal (Sugiyono, 2008:275). Uji Mann Whitney U-Test tidak memerlukan asumsi populasi berdistribusi normal, namun hanya mengasumsikan bahwa populasi tersebut mempunyai bentuk yang sama (Harinaldi, 2005:224). Penelitian ini nantinya akan membandingkan hasil pretest dengan hasil posttest untuk mengukur pengaruh perlakuan 
dan menarik kesimpulan.

\section{Hasil dan Pembahasan Hasil Penelitian}

Berdasarkan data hasil pretest dan posttest kelompok eksperimen, menghasilkan data sebagai berikut:

Tabel 4.1

Hasil Pretest dan Posttest Pemahaman Diri Siswa Kelompok Eksperimen

\begin{tabular}{|c|c|c|c|c|c|c|}
\hline No & Responden & \begin{tabular}{|c} 
Skor \\
Pretest
\end{tabular} & $\begin{array}{l}\text { Kategori- } \\
\text { sasi }\end{array}$ & $\begin{array}{c}\text { Skor } \\
\text { Posttest }\end{array}$ & $\begin{array}{l}\text { Kategori- } \\
\text { sasi }\end{array}$ & $\begin{array}{l}\text { Gain } \\
\text { Skor }\end{array}$ \\
\hline 1 & $\mathrm{AN}$ & 44 & Rendah & 66 & Sedang & 22 \\
\hline 2 & $\mathrm{AP}$ & 44 & Rendah & 60 & Sedang & 16 \\
\hline 3 & EM & 45 & Rendah & 65 & Sedang & 20 \\
\hline 4 & FA & 47 & Rendah & 66 & Sedang & 19 \\
\hline 5 & JA & 39 & Rendah & 59 & Sedang & 20 \\
\hline 6 & MK & 42 & Rendah & 57 & Sedang & 15 \\
\hline 7 & SA & 47 & Rendah & 66 & Sedang & 19 \\
\hline 8 & SP & 44 & Rendah & 60 & Sedang & 16 \\
\hline \multicolumn{2}{|r|}{ Rata-rata } & 44 & & 62,3 & & \\
\hline
\end{tabular}

Data-data tabel 4.1, dapat digambarkan melalui grafik sebagai berikut:

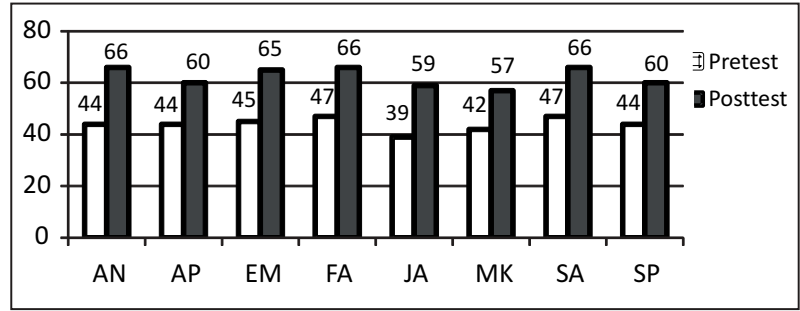

Gambar 4.1. Histogram Pretest dan Posttest Siswa Kelompok Eksperimen

Berdasarkan tabel 4.1 dapat dilihat bahwa hasil pretest pemahaman diri sebelum diberikan treatment berupa konseling kelompok dengan pendekatan Adlerian, tingkat pemahaman diri siswa kelompok eksperimen berada pada kategorisasi rendah. Skor rata-rata sebelum treatment diberikan mencapai 44.Setelah diberikan treatment terjadi peningkatan pada kategorisasi dan skor rata-rata dihasil posttest pemahaman diri siswa. Delapan siswa dikelompok eksperimen yang sebelumnya berada pada kategori rendah naik satu tingkat menjadi kategori sedang, begitu juga dengan skor rata-rata dari delapan siswa yang sebelumnya 44 naik menjadi 62,3, ini artinya terjadi peningkatan sebesar 18,3 pada skor rata-rata pemahaman diri siswa.
Berdasarkan data hasil pretest dan posttest dari kelompok kontrol yang telah diolah, didapatkan hasil sebagai berikut:

Tabel 4.2

Hasil Pretest dan Posttest Pemahaman Diri Siswa Kelompok Kontrol

\begin{tabular}{|c|c|c|c|c|c|c|}
\hline No & Responden & \begin{tabular}{|c} 
Skor \\
Pretest
\end{tabular} & $\begin{array}{l}\text { Kategori- } \\
\text { sasi }\end{array}$ & $\begin{array}{c}\text { Skor } \\
\text { Posttest }\end{array}$ & $\begin{array}{l}\text { Kategori- } \\
\text { sasi }\end{array}$ & $\begin{array}{l}\text { Gain } \\
\text { Skor }\end{array}$ \\
\hline 1 & $\mathrm{DH}$ & 41 & Rendah & 46 & Rendah & 5 \\
\hline 2 & $\mathrm{HN}$ & 45 & Rendah & 46 & Rendah & 1 \\
\hline 3 & $\mathrm{MN}$ & 44 & Rendah & 45 & Rendah & 1 \\
\hline 4 & NA & 42 & Rendah & 44 & Rendah & 2 \\
\hline 5 & OR & 46 & Rendah & 47 & Rendah & 1 \\
\hline 6 & RA & 43 & Rendah & 45 & Rendah & 2 \\
\hline 7 & $\mathrm{SI}$ & 45 & Rendah & 47 & Rendah & 2 \\
\hline 8 & SD & 40 & Rendah & 44 & Rendah & 4 \\
\hline \multicolumn{2}{|r|}{ Rata-rata } & 43,2 & & 45,5 & & \\
\hline
\end{tabular}

Data-data tabel 4.2, dapat digambarkan melalui grafik sebagai berikut:

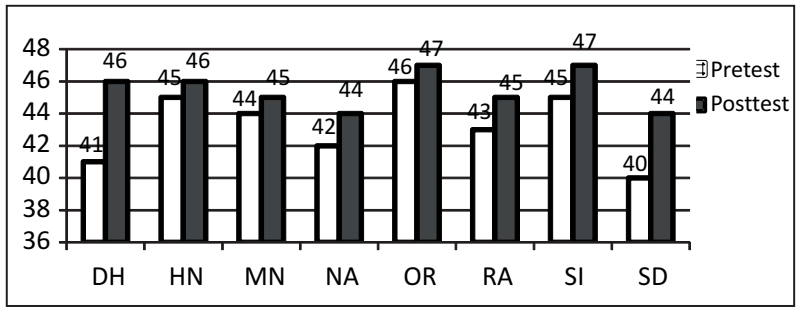

\section{Gambar 4.2. Histogram Pretest dan Posttest Siswa Kelompok Kontrol}

Tabel 4.2 menunjukan bahwa hasil pretest pemahaman diri siswa kelompok kontrol sebelum diberikan treatment berada pada kategori rendah. Skor rata-rata sebelum diberikan perlakuan mencapai 43,2. Kelompok kontrol tidak diberikan treatment berupa konseling kelompok dengan pendekatan Adlerian. Kelompok kontrol hanya diberikan tontonan film dan games tanpa ada tujuan khusus, selanjutnya semua anggota kelompok kontrol diberikan posttest. Skor rata-rata pada hasil posttest pemahaman diri siswa kelompok kontrol yaitu 45,5. Artinya terjadi peningkatan sebanyak 2,3 poin, namun semua siswa kelompok kontrol masih berada pada kategori rendah.

Berdasarkan hasil perhitungan dengan menggunakan Mann Whitney U-Test yang dilakukan dengan menggunakan aplikasi Statistic Product and Service Solution (SPSS) versi 17.0, diperoleh bahwa nilai Asymp. Sig sebesar 0.001 yang berarti nilai probalitas lebih kecil dari nilai signifikansi $\alpha$ 
0.005, yang artinya $\mathrm{H} 0$ ditolak dan $\mathrm{H} 1$ diterima, hal itu menandakan bahwa terjadi peningkatan pemahaman diri yang signifikan setelah diberikan perlakuan. Penjelasan di atas dapat ditarik kesimpulan bahwa konseling kelompok dengan pendekatan Adlerian memiliki pengaruh untuk meningkatkan pemahaman diri pada siswa kelas 5 SDN 01 Ujung Menteng.

\section{Pembahasan}

Uji hipotesis menunjukan bahwa konseling kelompok dengan pendekatan Adlerian dapat meningkatkan pemahaman diri siswa kelas 5 di SDN 01 Ujung Menteng.Hasil pretest menyebutkan terdapat enam belas siswa dengan pemahaman diri rendah, delapan diantaranya diberikan perlakuan berupa konseling kelompok dengan pendekatan Adlerian, sehingga menjadi kelompok eksperimen dan delapan siswa lainnya menjadi kelompok kontrol.Hasil menunjukan terdapat delapan siswa yang beranjak pada kategori sedang serta tidak ada lagi siswa yang berada pada kategori rendah di kelompok eksperimen.Hal ini berarti bahwa siswa yang menerima perlakuan berupa konseling kelompok dengan pendekatan Adlerian sudah lebih mampu memahami dan lebih mampu menerima keadaan dirinya.

Pengembangan pemahaman diri sangat penting dilakukan terutama untuk mengembangkan karakter baik dalam diri.Seperti yang dikemukakan oleh Thomas Lickona, bahwa salah satu aspek pengembangan karakter baik dalam diri seseorang adalah pemahaman diri. Selain itu, Lickona juga menjelaskan bahwa seseorang yang memiliki pemahaman diri dapat mengetahui kekuatan dan kelemahan yang dimiliki, sehingga orang tersebut mampu mengembangkan kekuatan dan menutupi kekurangannya, serta dapat mengevaluasi atas perilaku yang ditampilkan untuk menentukan mana yang baik dan buruk.

Pemahaman diri juga merupakan langkah awal yang diperlukan siswa SD dalam meraih kesuksesan, karena dengan memiliki pemahaman diri yang baik, siswa mengetahui kelebihan dan kekurangan yang dimiliki serta siswa tersebut mengetahui bagaimana cara yang tepat untuk mengembangkan dan menutupi kekurangan yang ada.

Kelebihan-kelebihan yang ada dalam diri meru- pakan aset dalam menjalani kehidupan sehari-hari, sehingga jika kelebihan-kelebihan yang telah ada tidak disadari dengan baik maka siswa tersebut akan kesulitan dalam mengembangkan diri. Begitupun sebaliknya, kekurangan-kekurangan yang ada dalam diri,jika tidak disadari dengan baik akan menjadi kendala/masalah bagi diri sendiri dalam menjalani kehidupan, sehingga nantinya akan menjadi gaya hidup yang melekat pada dirinya.

Berdasarkan deskripsi data sebelum dan sesudah pelaksanaan treatment, menunjukan bahwa konseling kelompok dengan pendekatan Adlerian mampu memberikan efek yang signifikan untuk meningkatkan pemahaman diri siswa. Terbukti pada tahapan pengungkapan psikologis siswa mulai menyadari apa saja pandangan-pandangan yang salah terhadap dirinya, sehingga pada tahapan reorientasi siswa mampu mengarahkan dirinya untuk membangun kembali tujuan dan gaya hidup yang sudah terbentuk. Hal itu dapat dilihat dari ciri-ciri yang mulai nampak pada diri siswa, seperti mulai memiliki penilaian realistis terhadap potensi-potensi yang dimilikinya, mulai menyadari kekurangan yang ada dalam diri, mulai memiliki rasa tanggung jawab terhadap perilakunya, dan mulai memiliki alasan pada setiap perbuatan yang dilakukan.

Ada beberapa faktor yang menyebabkan pendekatan Adlerian berpengaruh terhadap peningkatan pemahaman diri. Faktor pertama, anggota kelompok didorong untuk aktif dalam proses pembetukan hubungan terapetik atas dasar kerja sama dan saling menghargai, karena mereka bertanggung jawab tentang partisipasinya sendiri di dalam kelompok. Para penganut Adler berpendapat bahwa konseling, baik secara individual maupun berkelompok hanya akan berhasil jika proses terapetik terpusat pada hal-hal yang dianggap konseli sebagai sesuatu yang berarti secara pribadi.

Faktor kedua, dalam proses konseling kelompok dengan pendekatan Adlerian peneliti dapat menggali bagaimana hubungan anggota kelompok dengan keluarga dan hubungan anggota kelompok dengan lingkungannya, sehingga anggota kelompok dapat menceritakan kejadian-kejadian atau kenangan-kenangan khusus yang pernah dialami oleh anggota kelompok dalam kehidupannya. Pengungkapan kenangan masa lalu bukan hanya sekedar laporan, me- 
lainkan pemahaman mengenai gaya hidup para anggota kelompok yang keliru akibat keyakinan dan kesalahan yang mendasar yang ada dalam diri anggota kelompok.

Faktor ketiga, dalam suasana kelompok para anggota kelompok diarahkan untuk memahami mengapa mereka berfungsi dan berbuat seperti yang dilakukannya. Suasana kelompok memberikan kemudahan terhadap proses pengungkapan psikologis karena ketika ada salah satu anggota kelompok yang sedang menceritakan masalahnya terkait pemahaman diri, anggota kelompok yang lain juga ikut merasakan masalah yang sama, sehingga mereka melihat dirinya dalam diri orang lain. Dengan demikian mereka bisa saling menolong satu dengan yang lainnya.

Faktor keempat, karena pendekatan Adlerian membantu para anggota kelompok untuk melakukan reorientasi terhadap pertimbangan tentang berbagai pilihan atau alternatif mengenai sikap-sikap, keyakinan, tujuan-tujuan dan perilaku, sehingga para anggota kelompok mampu berinteraksi di lingkungannya dengan baik karena mereka telah mengetahui yang harus dikembangkan sesuai dengan kemampuan yang dimiliki, dan mereka pun berusaha untuk mengatasi kekurangan yang ada dengan cara-cara positif bukan pelampiasan-pelampian yang malah akan merugikan dirinya. Berdasarkan pembahasan di atas, konseling kelompok dengan pendekatan Adlerian dapat diterapkan untuk meningkatkan pemahaman diri siswa kelas 5 SDN 01 Ujung Menteng.

\section{Kesimpulan dan Saran}

Berdasarkan penelitian yang telah dilakukan, maka konseling kelompok dengan pendekatan Adlerian merupakan salah satu bentuk intervensi yang dapat digunakan untuk menangani siswa kelas 5 SDN 01 Ujung Menteng yang mengalami masalah terhadap pemahaman diri.Hal itu terbukti dari hasil posttest yang mengalami peningkatan dibandingkan dengan hasil pretest.Konseling kelompok dengan pendekatan Adlerian juga memberikan kesempatan kepa- da siswa untuk saling terbuka kepada teman sebaya-nya mengenai hal-hal penting yang ada di dalam dirinya. Selain itu, dalam konseling kelompok dengan pendekatan Adlerian konselor berkesempatan untuk memotivasi siswa untuk menjadi orang yang lebih baik, berani dan mau berusaha untuk merubah perilaku buruk menjadi perilaku baik, serta mengembangkan pemikiran positif terhadap diri siswa.

Saran-saran yang dapat menjadi pertimbangan berdasarkan hasil penelitian pengaruh konseling kelompok dengan pendekatan Adlerian yang telah dilakukan, yaitu: bagi kepala sekolah SDN 01 Ujung Menteng semoga tetap dapat bekerja sama dan mendukung penuh kegiatan bimbingan dan konseling di SD, Lalu untuk guru atau konselor sekolah disarankan untuk menerapkan konseling kelompok dengan pendekatan Adlerian untuk mengatasi masalah pemahaman diri siswa di SD, karena siswa SD senang berkegiatan dalam kelompok dan bagi peneliti selanjutnya, hendaknya memperdalam kajian teoritis mengenai peningkatan pemahaman diri dan pendekatan Adlerian yang dapat digunakan untuk meningkatkan pemahaman diri siswa.

\section{Referensi}

Alwisol. 2011. Psikologi Kepribadian. Malang: UMM Press.

Cavell, Marcia. 1990. Psychology of Adjustment and Human Relationship. New York:

McGraw Hill Publishing Company.

Lickona, Thomas. 1991. Educating for Character How Our School Can Teach Respect

and Responsibility. USA: Bantam Books.

Sonstegard, Manford A. 2004. Adlerian Group Counseling and Therapy: Step By Step.

New York: Brunner-Routledge.

Sugiyono. 2008. Metodologi Penelitian Kuantitatif, Kualitatif, dan R\&D. Bandung:

Alfabeta.

Sugiyono. 2008. Statistika Untuk Penelitian. Bandung: Alfabeta.

Supratik, Ahmad. 1993. Psikologi Kepribadia: Teori-teori Psikodinamik (Klinis).

Yogyakarta: Kanisius. 